\title{
FLORA OF TOXIC DEPOTS IN SELECTED INDUSTRIAL ZONES
}

\author{
PeTr PETŘíK ${ }^{1}$, PeTr SOUdeK ${ }^{2 *}$, DAGMAR BENEŠOVÁ², \\ PETRA NAJMANOVÁ ${ }^{3}$, Michal NAJMAN ${ }^{3}$, TOMÁŠ VANĚK ${ }^{2}$ \\ ${ }^{1}$ Department of Geobotany, Institute of Botany, v. v. i., Academy of Sciences of the Czech Republic \\ Zámek 1, 25243 Průhonice, Czech Republic \\ ${ }^{2}$ Laboratory of Plant Biotechnologies, \\ Joint Laboratory of Institute of Experimental Botany, Academy of Sciences of the Czech Republic, \\ v. v. i. and Crop Research Institute, v. v. i. \\ Rozvojová 263, 16502 Prague 6, Czech Republic \\ e-mail:soudek@ueb.cas.cz \\ ${ }^{3}$ DEKONTA Inc. \\ Dřetovice 109, 27342 Stehelčeves, Czech Republic
}

(Received: December 18, 2008. Accepted: July 21, 2009)

\begin{abstract}
Floristic composition in three industrial areas with soils contaminated by heavy metals (As, $\mathrm{Cd}, \mathrm{Cu}, \mathrm{Hg}, \mathrm{Pb}$, $\mathrm{Zn}$ ) and organic pollutants (polychlorinated biphenyls) was studied. The content of $\mathrm{Pb}$ was only significantly correlated with the floristic composition and explained $13.8 \%$ of its variability considering spatial dependency of the sites. No correlation was found for PCBs. Altogether, 237 plant vascular species were found at three study sites (117, 133 and 105, respectively). The three study areas differed in their species composition represented by their own characteristic species. The gradient in the content of natives/non-natives, species number, prevailing life forms and indicator values for plant species investigated was revealed. Based on our results, for phytoremediation purposes we can select productive plant species with high biomass and ability to accumulate large amounts of heavy metals or organic compounds and surviving on soils with low mineral content.
\end{abstract}

KEY WORDS: bioindication, Ellenberg indicator values, heavy metals, phytoremediation, polychlorinated biphenyls.

\section{INTRODUCTION}

Importance of environmental pollutants has been recognized internationally (see e.g. EC regulation No 1907/2006 Registration, Evaluation, Authorisation and Restriction of Chemical substances) and, based on precautionary principle, their occurrence is intensively monitored in all developed countries.

Nevertheless, many wastes and noxious residua (heavy metals and polychlorinated biphenyls PCBs, particularly) are buried in soil usually in the vicinity of industrial areas or within them as remnants of the previous companies' management, which had totally ignored basic principles of environment-friendly waste treatment (Rebele et al. 1993). Fortunately, after political changes in most post-communistic countries, the industry was structurally transformed, contributing less to environmental pollution and natural habitat degradation. In the Czech Republic, Ministry of the Environment has recently adopted methodology for environmental management accounting and companies ought to measure and monitor identified pollutant emissions following the operation permits of Integrated Prevention and Pollution Control (IPPC). Most industrial companies have contingency plans and training for extraordinary situations that may occur - in temperate regions it is the leaching of toxics into water drainage and eolian erosion in arid regions are the most frequent (see Mendez and Maier 2008).

High concentrations of heavy metals or organic pollutants limit the colonization process or plant growth (see Kučerová et al. 2001) but it could be a selection factor for naturally stress-tolerant species. Based on knowledge of natural conditions with noxious substrate (e.g. arsenic in serpentine bedrock), we have the opportunity to find some natural biological accumulators with high bioavailability to heavy metals (so called hyperaccumulators, see Brej and Fabiszewski 2006) in order to restore sites degraded by human activity (e.g. mine tailings). Using accumulation and utilisation of the pollutants in plant issues is a promising way for phytoremediation activities (see e.g. Adriano et al. 2004; Soudek et al. 2007). Thus, to help with environmental detoxication, the studies on vascular plant species indicating the harmful pollutants in the substrates polluted by heavy metals or PCBs from industrial activities are urgently needed.

The knowledge on plant cover could be useful both for phytoextraction (bioaccumulation) and for phytostabilization (immobilization of specific elements) (Mendez and 
Maier 2008). Based on knowledge on species composition of naturally recovered toxic sites, we are able to select resistant species either to accumulate or stabilize toxic elements in a substrate. However, such selection should be experimentally tested utilizing modern approaches such as interactions with mycorrhiza and considering possible threats (e.g. potential invasiveness of the species if using noninvasive plants or gene flow when using genetically modified plants).

The goal of phytoremediation (plant-based remediation) processes is to eliminate the impact of contaminants on living organisms using plants to extract or to stabilize the poisonous conditions. Prior to the selection of appropriate plants, we have to find a correlation between toxic conditions (critical content of arsenic, copper, zinc, mercury, lead, cadmium and PCBs in soil) and the plant cover. This paper is therefore aimed at geobotanical survey description of two sites with deposits of heavy metals in the Czech Republic and another one in the Slovak Republic (containing old residua of PCBs).

\section{METHODS}

Study areas (for description see Fig. 1)

\section{Kovohutě Př́bram}

The locality Kovohutě Př́bram in the Czech Republic (49 $\left.42^{\prime} 26.514^{\prime \prime} \mathrm{N}, 13^{\circ} 58^{\prime} 58.589^{\prime \prime} \mathrm{E}\right)$ is situated in the area of Kovohutě Př́bram nástupnická, a.s. The whole history of metallurgy in Př́ibram is inseparably connected with mining activities in this city. The mining and production of silver then subsequently accelerated the production of lead, using domestic lead concentrates until 1973, and thereafter the lead waste entirely. The lead wastes consist mainly of used vehicle accumulators, processed for raw lead, lead alloys and lead products. Three sampling and experimental areas with high concentrations of toxic metals were chosen on the basis of soil analysis.

\section{Spolana Neratovice}

The history of chemical factory in Neratovice, Czech Republic $\left(50^{\circ} 15^{\prime} 50.053^{\prime} ' \mathrm{~N}, 1^{\circ} 31^{\prime} 28.427^{\prime}, \mathrm{E}\right)$ starts in 19 th century. The first products were oil, stearine, soap and candles. For a few decades, the food production (chocolate,

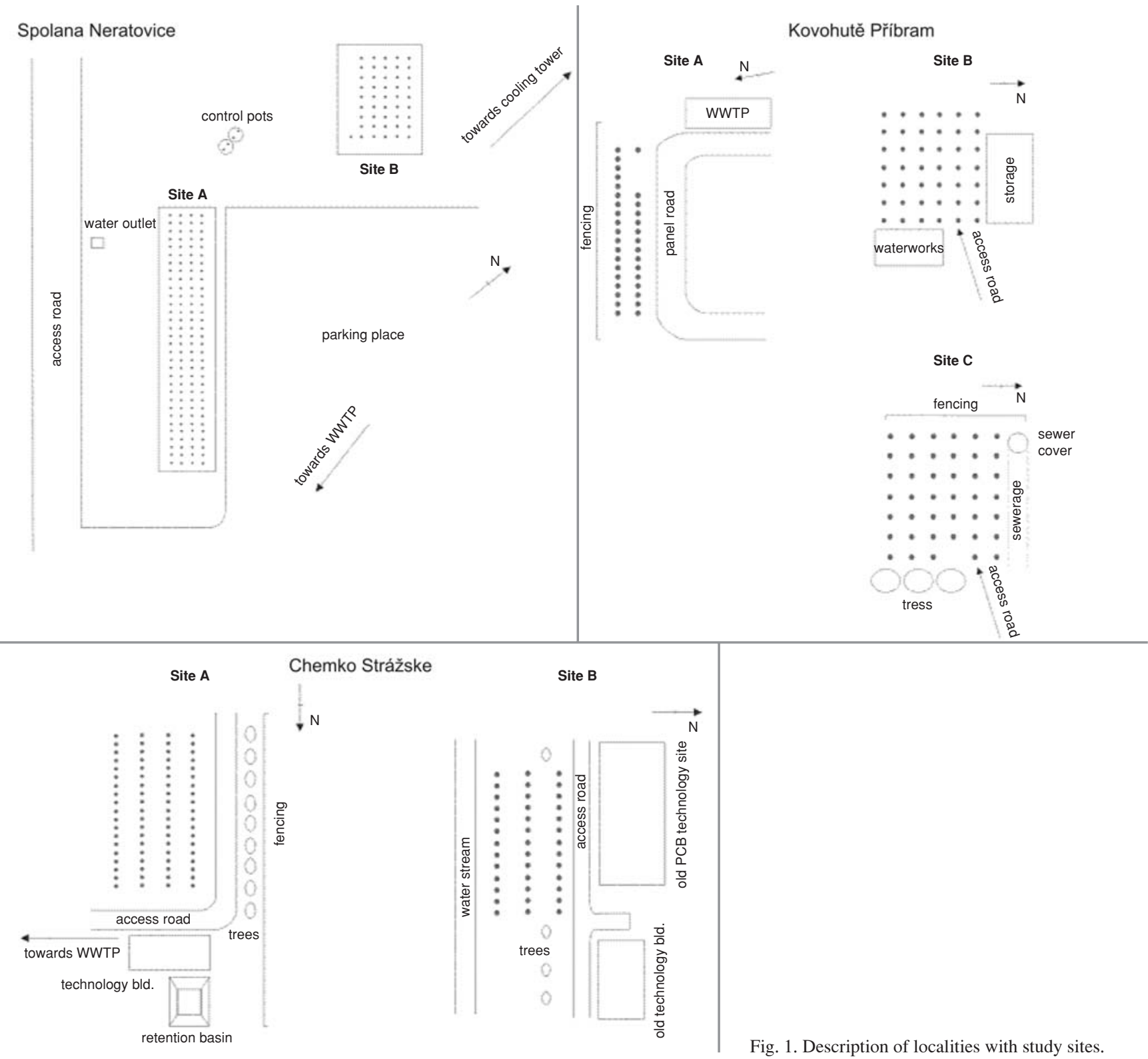




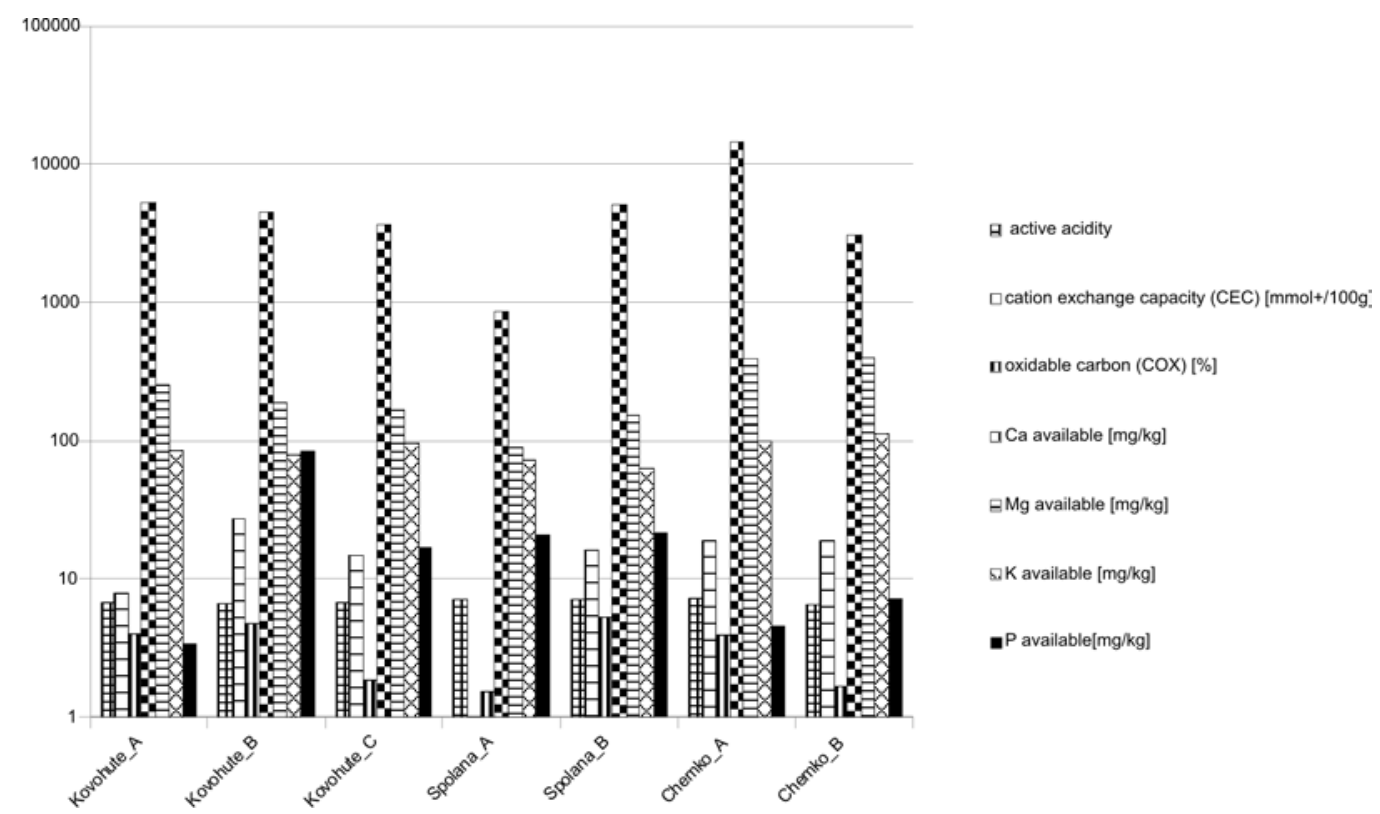

Appendix 1. Content of selected soil chemical properties for three sites studied. The units in vertical axis are listed in legend and logarithmized. sweets, marmalade etc.) have been driven out the chemistry. In 1947, the production of viscose has been started and, since this time, chemical production in Spolana was gradually expanded to chlorine and sodium hydroxide by electrolysis, bone glue, fat, cellophane, hydrochloric acid, caprolactam and PVC.

\section{Chemko Strážske}

A chemical factory in East Slovakia near the village of Strážske (48 $52^{\prime} 32.15^{\prime} \mathrm{N}, 21^{\circ} 48^{\prime} 56.57^{\prime}$ 'E) has been in operation since 1952. In the past, the factory has been producing explosives and intermediates for military and civil purposes such as PCB. However, in the 90's, the situation in the market has changed and the economically unviable production of explosives have been suspended in 2003 and finally terminated on 1 January 2005 . At present, the subsidiaries - Chemza, a.s. and Hnojivá, a.s. - produce industry-leading chemical products of inorganic and organic chemistry and their intermediates, nitric acid and nitration mixtures for the production of nitrogen fertilisers.

\section{Soil sampling and chemical analyses}

To assess general soil properties in study areas, available $\mathrm{Ca}, \mathrm{K}, \mathrm{Mg}, \mathrm{P}$ in $\mathrm{mg} \cdot \mathrm{kg}^{-1}$ of dry soil, cation exchange capacity in $\mathrm{mmol} / 100 \mathrm{~g}$ of dry biomass, $\mathrm{pH}$ value in water solution, and percentage of oxidable carbon were determined from seven samples (see Appendix 1). To describe substrate toxicity in detail, 22 soil samples were further taken in Kovohutě and Spolana and contents of heavy metals (As, $\mathrm{Cd}, \mathrm{Cu}$ - for Kovohutě only, $\mathrm{Hg}, \mathrm{Pb}, \mathrm{Zn}$ ) in $\mathrm{mg} \cdot \mathrm{kg}^{-1}$ of dry soil were measured (see Appendix 2). The content of polychlorinated biphenyls PCBs was measured for Chemko Strážské only.

To determine the basic soil properties, the samples were analyzed in a commercial laboratory. Analyses were carried out according to standards ISO 14235 (organic carbon), ISO 13536 (CEC), ISO 11277 (soil granulity), ČSN ISO 10390 (exchangeable pH) and public notice of the Czech Ministry of Agriculture Nr. 275/1998 Coll. (determination of available nutrients).

The dried soils were digested in $5 \mathrm{~cm}^{3}$ of acid mixture of $\mathrm{HClO}_{4}$ and $\mathrm{HNO}_{3}(15 / 85 \% \mathrm{v} / \mathrm{v})$ in digestion glass tubes overnight. Digestion was completed by a gradual increase of temperature from 60 to $195^{\circ} \mathrm{C}$. Digestion protocol: $3 \mathrm{~h}\left(60^{\circ} \mathrm{C}\right) ; 1 \mathrm{~h}\left(100^{\circ} \mathrm{C}\right) ; 1 \mathrm{~h}\left(120^{\circ} \mathrm{C}\right) ; 3 \mathrm{~h}\left(195^{\circ} \mathrm{C}\right)$. After cooling, $\mathrm{HCl}(20 \%), 2.5 \mathrm{~cm}^{3}$ was added, whirl mixed and warmed to $80^{\circ} \mathrm{C}$ for one hour. The final volume was brought between 5 to $10 \mathrm{~cm}^{3}$ accurately. The heavy metal content was measured by AAS (SensAA, GBC, Australia) (Barazani et al. 2004).

PCB soil samples were extracted by n-hexane, polar phase was separated and polar compounds were removed by silicagel. Aliquot amounts of samples were analyzed on a Hewlett-Packard 5890 gas chromatograph with an electron capture detector and a fused silica capillary column (30 $\mathrm{m}, 0.32 \mathrm{~mm}$ inner diameter) coated with $0.25 \mu \mathrm{m}$ immobilized phase of methyl-polysiloxane (5\% phenyl) and nitrogen as a carrier gas (at the constant pressure $9 \mathrm{psi}$ ). The temperature program was $70^{\circ} \mathrm{C}$ for $0.5 \mathrm{~min}$, then $25^{\circ} \mathrm{C} \cdot \mathrm{min}^{-1}$ until $200^{\circ} \mathrm{C}, 10^{\circ} \mathrm{C} \cdot \mathrm{min}^{-1}$ until $260^{\circ} \mathrm{C}$, then isothermically $3.7 \mathrm{~min}$, $25^{\circ} \mathrm{C} \cdot \mathrm{min}^{-1}$ until $300^{\circ} \mathrm{C}$, then isothermically $1 \mathrm{~min}$. The sample amount injected was $1 \mu \mathrm{l}$ in splitless mode. All of the seven congeners were identified by comparing their retention times with the retention times of corresponding peaks of PCB Congener Standard - RESTEK.

\section{Botanical field survey}

Within each locality, all vascular plant species were recorded in 6-14 samples of $2 \times 2 \mathrm{~m}$ (the uneven number of samples was due to the varying sizes of each study area). The data on species composition were sampled twice in vegetation period (late summer 2007 and spring 2008) in order to cover important plant phenophases, an additional sampling for whole areas was performed so the final number of plots for classification reached 36 .

\section{Species data adjustment}

To substitute missing information on selected soil properties, Ellenberg indicator values (Ellenberg et al. 1992) were used. These values are proxies for evaluation of site conditions for light, nutrients (productivity), continentality, temperature, soil reaction and moisture.

To employ species functional groups, their life forms according to C. Raunkiær (i.e. hemicryptophytes were classi- 


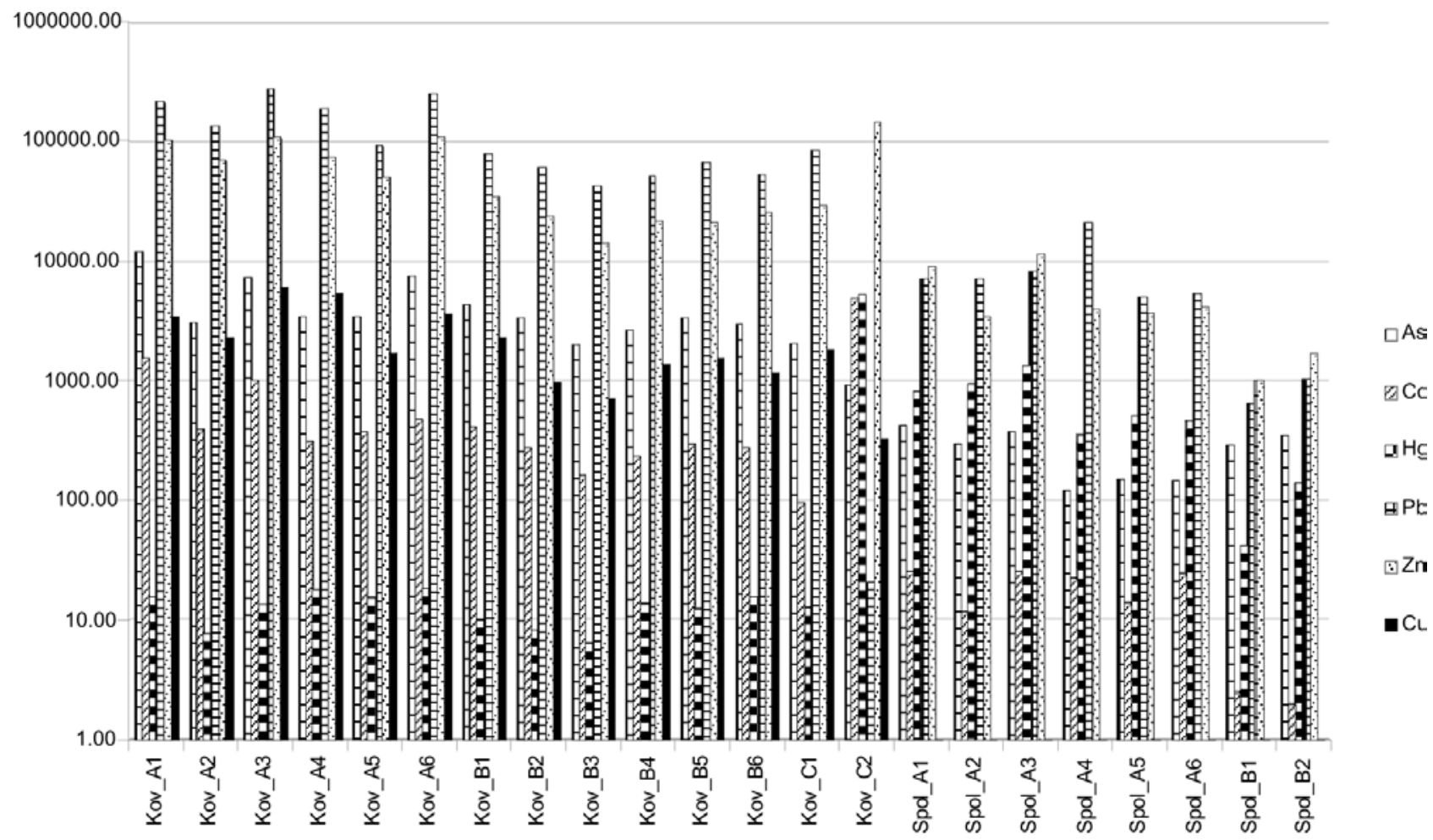

Appendix 2. Content of six heavy metals from two study sites (Kovohutě and Spolana) investigated at 22 sample plots. The data are presented as mg.kg-1 of dry biomass $* 10$ and shown in the logarithmic scale. Copper content was not measured at Spolana site.

fied - species with germinating buds above or at the soil ground - usually rhizomatous or tussock species, phanerophytes - trees and shrubs, terophytes - annuals surviving the unfavourable period in seeds, geophytes - species with vegetative organs in ground).

To assess original distribution areas of the species they were further classified as natives and non-natives (including neophytes, i.e. those brought to Europe after 1500 and archeophytes as those introduced before this date) according to Pyšek et al. (2002), and species number per plot was added.

Nomenclature of plant taxa follows Kubát et al. (2002) and all data adjustment was performed in the JUICE software (Tichý 2002).

\section{Statistical analysis}

To classify all 36 systematically sampled presence/absence data, a divisive classification TWINSPAN (Hill 1979) for all study areas was performed in the JUICE software (Tichý 2002). Diagnostic species typical of each study area were selected based on statistical tendency (measured by phi coefficient) of co-occurring species, which are more frequent than would be expected randomly (Bruelheide 2000; see Petřík and Bruelheide 2006 for using of species floristic data).

To discern trends in the composition of species and passive variables (i.e. indicator values, species number, native status, and life form) at all three study sites, the unconstrained linear ordination Principal Component Analysis (PCA) in CANOCO for Windows 4.0 (Ter Braak and Šmilauer 2002) was launched. For the assessment of species composition-environment correlations (i.e. the data set with environmental variables of soil properties and those containing species occurrences), a linear ordination method Redundancy Detrended Analysis (RDA) was performed for two sites with complete soil data as the length of gradients were too short. To filter out the spatial dependency of the data, the localities as covariables were used. To find the minimum number of statistically significant environmental variables, a manual forward selection procedure with 999 Monte Carlo significance permutation tests was used. The eigenvalues and percentages of floristic variance explained by all canonical axes were than calculated.

\section{RESULTS}

\section{Soil samples}

The basic chemical soil properties were comparable in all study areas (Appendix 1). The lowest values of oxidable carbon was found at all plots (namely plot $\mathrm{C}$ in Kovohutě, plot A in Spolana and plot B in Chemko) followed by lower cation exchange capacity and bases (except of $\mathrm{Mg}$ and $\mathrm{P}$ where the values varied independently of other bases) in humus layer. The content of two base cations was significantly different from the other at Chemko site (for $\mathrm{Mg}$ the $F$ value = $27.46, P=0.0046$, for $\mathrm{K}$ the $F$ value is $11.225, P=0.0229)$.

All sites differed significantly in content of As $(F=$ 14.395, $P=0.003), \mathrm{Pb}(F=12.244, P=0.0023)$ and $\mathrm{Zn}$ $(F=12.777, P=0.0019)$. Compared to Spolana sites, Kovohutě was rich in all heavy metals investigated, with only one exception (plot C2) with low lead content (see Appendix 2). The arsenic reached up to $1180 \mathrm{ppm}$ and, cadmium, up to $479 \mathrm{ppm}$ was measured in one soil sample. The only exception was mercury (510 ppm), cadmium (479 ppm) and zinc (14380 ppm) at plot number C2 with extraordinary high values. Interestingly, this plot had the lowest amount of lead residua from all sites.

PCBs content was recognized only in Chemko and its values differ up to ten times between plots within this study area. Values of the PCBs in $\mathrm{mg} \cdot \mathrm{kg}^{-1}$ of dry soil are as 
follows: $0.027,0.046,0.058,0.063,0.077,0.11,0.17,0.18$ at the first plot and $0.38,0.43$ at the second plot.

\section{Species composition at study sites}

Totally, 237 plant vascular species were found in three study areas (117 in Chemko, 133 in Kovohutě and 105 in Spolana). The three study areas differed in their species composition and every site was well represented by its own characteristic species (see Table 1). In Chemko site the species were typical of vegetation of moist meadows and pastures, whereas in Kovohutě the vegetation was similar to dry and mesic meadows with many ruderal plants. Quite unique vegetation has been developed in Spolana where under regular disturbances many annual and alien species occur (see further).

The results of PCA (Fig. 2) show gradients in the occurrence of natives/non-natives (including neophytes and archeophytes), species number, prevailing life forms and indicator values for plant species investigated. There were logically large differences among species composition of sites studied rather than the differences in their internal variability. The only exception was vegetation of Kovohutě of which the composition was most diverse and could be classified into two groups alongside the second PCA axis due to the significant gradient in productivity (or nutrient) based on indicator values and prevailing life form of plants. The position of Kovohutě vegetation in ordination space was well associated with high amount of natives and hemicryptophytes/phanerophytes (both are intercorrelated variables) and high supply for moisture. On the opposite gradient wing there is the relatively species-rich and unified vegetation of Spolana with many neophytes/ archeophytes, with life-form of terophytes, with higher demand to light/continentality/temperature (mutually correlated variable) and soil reaction. The central position in ordination space was occupied by Slovak Chemko plots, represented by a relatively higher occurrence of geophytes.

\section{Correlation of species composition with soil properties}

Considering the sites as covariables, from five heavy metals analysed only the content of $\mathrm{Pb}$ was shown to be significant for vegetation composition of the two sites compared (see Fig. 3) and totally explained $13.8 \%$ of total variance in species data at the significance level $P=0.002$ $(F=3.04)$, and was highly positively correlated (inter set correlation coefficient $=0.81$ ) with the first canonical axis.

\section{DISCUSSION}

\section{Soil properties and species composition correlations}

The basic soil properties are apparently similar at all study sites and could be characterised as neutral up to slightly alcalic soil with slightly to moderately humose soil with high content of bases and varying cation exchange capacity. As the soil conditions are similar (except of two basic cations content), no specific plants were found to be correlated with these properties.

There were significant group of species recognised to be bound with higher content of $\mathrm{Pb}$ ions (see Fig. 2). To prove these species to be tolerant to high heavy metal content, habitats with similar conditions with ore-washery or ashslag deposits in the Czech Republic could be compared
TABLE 1. Species composition at three study sites (column 1 - Chemko, column 2 - Kovohutě, 3 - Spolana) classified by TWINSPAN divisive method and sorted according the decreasing fidelity based on phi coefficient phi $\geq 0.50$ (**). Species characteristic for each column are ranked by a decreasing fidelity. Phi coefficient standardized to all group size of the total data set was used. Diagnostic species with probability of observed occurrence concentration in the given column (group of samples) higher than $P<0.01$ (Fisher's exact test) were excluded. Number of sample plots for every study area is listed with species frequency in each column.

\begin{tabular}{|c|c|c|c|}
\hline $\begin{array}{l}\text { Study area no. } \\
\text { No. of relevés }\end{array}$ & $\begin{array}{l}1 \\
9\end{array}$ & $\begin{array}{c}2 \\
17\end{array}$ & $\begin{array}{c}3 \\
10\end{array}$ \\
\hline Acer negundo & $78^{* * *}$ & . & . \\
\hline Pastinaca sativa & $78^{* *}$ & . & . \\
\hline Galium album & $89^{* *}$ & 18 & . \\
\hline Dactylis glomerata & $89^{* *}$ & 12 & 20 \\
\hline Symphytum officinale & $56^{* *}$ & . & . \\
\hline Potentilla anserina & $56^{* *}$ & . & . \\
\hline Erigeron annuus & $100^{* * *}$ & . & 80 \\
\hline Silene vulgaris & . & $88^{* *}$ & . \\
\hline Festuca rubra & 22 & $82^{* *}$ & . \\
\hline Holcus lanatus & . & $59^{* * *}$ & . \\
\hline Rumex acetosa & 33 & $88^{* *}$ & . \\
\hline Cerastium holosteoides & 44 & $94^{* *}$ & . \\
\hline Capsella bursa-pastoris & . & $76^{* * *}$ & 20 \\
\hline Herniaria glabra & . & $53^{* *}$ & . \\
\hline Vicia cracca & . & $53^{* * *}$ & . \\
\hline Trifolium repens & 11 & $65^{* * *}$ & . \\
\hline Populus tremula & 11 & $65^{* *}$ & 10 \\
\hline Senecio vulgaris & . & . & $100^{* * *}$ \\
\hline Papaver dubium agg. & . & 6 & $80^{* * *}$ \\
\hline Crepis foetida ssp. rhoeadifolia & . & . & $70^{* * *}$ \\
\hline Arenaria serpyllifolia & . & . & $60^{* *}$ \\
\hline Datura stramonium & . & . & $60^{* *}$ \\
\hline Lactuca serriola & 11 & . & $70^{* * *}$ \\
\hline Viola arvensis & . & 12 & $70^{* * *}$ \\
\hline Fallopia convolvulus & 11 & 6 & $70^{* *}$ \\
\hline Digitaria ischaemum & . & . & $50^{* * *}$ \\
\hline Senecio jacobaea & 22 & . & $70^{* * *}$ \\
\hline Achillea millefolium & 100 & 94 & 100 \\
\hline Taraxacum sect. Ruderalia & 89 & 88 & 100 \\
\hline Daucus carota & 78 & 59 & 90 \\
\hline Arrhenatherum elatius & 89 & 53 & 40 \\
\hline Poa pratensis & 67 & 53 & 60 \\
\hline Tanacetum vulgare & 78 & 35 & 70 \\
\hline Poa compressa & 67 & 29 & 90 \\
\hline Poa palustris & 78 & 35 & 50 \\
\hline Calamagrostis epigejos & 67 & 18 & 90 \\
\hline Medicago lupulina & 67 & 29 & 70 \\
\hline Cirsium arvense & 89 & 6 & 80 \\
\hline Tripleurospermum inodorum & 11 & 53 & 70 \\
\hline Urtica dioica & 89 & 47 & . \\
\hline Artemisia vulgaris & 44 & 41 & 50 \\
\hline Plantago major agg. & 56 & 53 & . \\
\hline Elytrigia repens & 78 & 6 & 50 \\
\hline Plantago lanceolata & 67 & 18 & 40 \\
\hline Veronica arvensis & . & 41 & 60 \\
\hline Equisetum arvense & 56 & 35 & 10 \\
\hline Arabidopsis thaliana & . & 59 & 20 \\
\hline Ranunculus repens & 78 & 24 & . \\
\hline Trifolium pratense & 33 & 47 & . \\
\hline Securigera varia & . & 18 & 70 \\
\hline Carex hirta & 56 & 18 & 10 \\
\hline Lolium perenne & 56 & 18 & 10 \\
\hline Agrostis capillaris & 22 & 41 & . \\
\hline Hypericum perforatum & 22 & 12 & 50 \\
\hline Silene latifolia & 44 & 24 & 10 \\
\hline Fraxinus excelsior & 11 & 41 & 10 \\
\hline Verbascum thapsus & . & 41 & 20 \\
\hline Echium vulgare & . & 29 & 40 \\
\hline Ranunculus acris & 11 & 41 & . \\
\hline
\end{tabular}


TABLE 1. Cont.

\begin{tabular}{|c|c|c|c|}
\hline $\begin{array}{l}\text { Study area no. } \\
\text { No. of relevés }\end{array}$ & $\begin{array}{l}1 \\
9\end{array}$ & $\begin{array}{c}2 \\
17\end{array}$ & $\begin{array}{c}3 \\
10\end{array}$ \\
\hline Chenopodium album agg. & . & 12 & 60 \\
\hline Stellaria media & . & 29 & 30 \\
\hline Erodium cicutarium & . & 12 & 60 \\
\hline Glechoma hederacea & 22 & 29 & . \\
\hline Tussilago farfara & 33 & 24 & . \\
\hline Rumex crispus & 56 & . & 20 \\
\hline Lotus corniculatus & 22 & 18 & 20 \\
\hline Lamium album & 22 & 24 & 10 \\
\hline Aegopodium podagraria & . & 41 & . \\
\hline Heracleum sphondylium & . & 41 & . \\
\hline Setaria pumila & 56 & . & 10 \\
\hline Arctium minus & 33 & 12 & 10 \\
\hline Rumex obtusifolius & 11 & 29 & . \\
\hline Rubus sect. Corylifolii & 11 & 24 & 10 \\
\hline Sonchus oleraceus & 11 & . & 50 \\
\hline Oenothera species & 11 & . & 50 \\
\hline Salix caprea & . & 35 & . \\
\hline Verbascum nigrum & . & 6 & 50 \\
\hline Myosotis stricta & . & 12 & 40 \\
\hline Leontodon autumnalis & 44 & 6 & . \\
\hline Galium aparine & 22 & . & 30 \\
\hline Calystegia sepium & 44 & 6 & . \\
\hline Conyza canadensis & 22 & . & 30 \\
\hline Trifolium campestre & 11 & 6 & 30 \\
\hline Betula pendula & . & 29 & . \\
\hline Poa nemoralis & . & 29 & . \\
\hline Pinus sylvestris & . & 29 & . \\
\hline Knautia arvensis & . & 29 & . \\
\hline Campanula patula & . & 12 & 30 \\
\hline Lythrum salicaria & 44 & . & . \\
\hline Mentha longifolia & 44 & . & . \\
\hline Rorippa sylvestris & 44 & . & . \\
\hline Picris hieracioides & 44 & . & . \\
\hline Geum urbanum & 44 & . & . \\
\hline Potentilla argentea & 22 & 6 & 10 \\
\hline Cirsium vulgare & 11 & . & 30 \\
\hline Rubus mollis & 44 & . & . \\
\hline Chenopodium polyspermum & 11 & 18 & . \\
\hline Crepis biennis & 22 & 12 & . \\
\hline Senecio viscosus & 11 & . & 30 \\
\hline Myosotis arvensis & 11 & 18 & . \\
\hline Convolvulus arvensis & 11 & . & 30 \\
\hline Spergularia rubra & . & 24 & . \\
\hline Роа аппиа & . & 24 & . \\
\hline Moehringia trinervia & . & 24 & . \\
\hline Rumex acetosella & . & 24 & . \\
\hline Geranium pusillum & . & 18 & 10 \\
\hline Carex ovalis & . & 24 & . \\
\hline Vicia tetrasperma & . & 24 & . \\
\hline Lamium amplexicaule & . & . & 40 \\
\hline Cerastium semidecandrum & . & . & 40 \\
\hline Solanum nigrum & . & . & 40 \\
\hline Linum perenne & . & . & 40 \\
\hline Ajuga reptans & 33 & . & . \\
\hline Echinochloa crus-galli & 11 & . & 20 \\
\hline Lysimachia nummularia & 33 & . & . \\
\hline Carpinus betulus & 33 & . & . \\
\hline Quercus robur & 11 & 12 & . \\
\hline Agrostis stolonifera & 33 & . & . \\
\hline Persicaria maculosa & 11 & . & 20 \\
\hline Leucanthemum vulgare agg. & . & 18 & . \\
\hline Trifolium arvense & . & 18 & . \\
\hline Picea abies & . & 18 & . \\
\hline Hieracium sabaudum & . & 18 & . \\
\hline Vicia sepium & . & 18 & . \\
\hline Cirsium palustre & . & 18 & . \\
\hline Viola tricolor & . & 18 & . \\
\hline
\end{tabular}

TABLE 1. Cont.

\begin{tabular}{lccc}
\hline Study area no. & 1 & 2 & \\
No. of relevés & 9 & 17 & 10
\end{tabular}

Cardaminopsis halleri . . 18

Vicia hirsuta

Sisymbrium altissimum

Bromus sterilis

Polygonum aviculare

Cerastium glutinosum

Papaver argemone

Deschampsia cespitosa

Cichorium intybus

Bidens frondosa

Prunus avium

Anagallis arvensis

Epilobium sp.

Rumex confertus

Veronica persica

Amaranthus sp.

Rosa canina s.1.

Malus domestica

Epilobium lamyi

Acer pseudoplatanus

Humulus lupulus

Melilotus albus

Oxalis fontana

Myosoton aquaticum

Arctium lappa

Salix purpurea

Atriplex patula

Erysimum cheiranthoides

Trifolium hybridum

Hypochaeris radicata

Linaria vulgaris

Veronica chamaedrys

Malva neglecta

Polygonum arenastrum

Salix fragilis

Erysimum durum

Campanula rapunculoides

Trifolium dubium

Reseda lutea

Vicia sativa

Papaver rhoeas

Arctium sp.

Rumex thyrsiflorus

Thlaspi arvense

Oenothera biennis

Bromus tectorum

Nepeta cataria

Rubus caesius

Eragrostis minor

Amaranthus albus

3
10

30

30

30

22

22

22

22

11

22

22

11

10

10

10

10

10

10

.

.

Species presented only once:

In column 1: Potentilla reptans; Sonchus arvensis; Persicaria amphibia; Barbarea vulgaris; Plantago media; Inula britannica; Lathyrus pratensis; Euonymus europaea; Robinia pseudacacia; Solidago canadensis; Clematis vitalba; Cornus sericea; Eupatorium cannabinum; Cornus sanguinea; Agrostis gigantea; Lathyrus tuberosus; Viola odorata; Festuca pratensis; Prunella vulgaris; Clinopodium vulgare; Prunus padus;

In column 2: Carex sp.; Hieracium species; Persicaria lapathifolia; Setaria viridis; Larix decidua; Salix alba; Microrrhinum minus; Crepis capillaris; Festuca arundinacea; Epilobium montanum; Erigeron acris s.l.; Sedum sexangulare; Phleum pratense; Galinsoga quadriradiata; Artemisia absinthium; Euphorbia helioscopia; Sinapis arvensis; Carex muricata agg.; Sonchus asper, Carex brizoides; Trisetum flavescens; Pimpinella saxifraga; Torilis japonica; Sedum acre; Stellaria graminea; Astragalus glycyphyllos; Odontites vernus;

In column 3: Tragopogon pratensis; T. dubius; Vulpia myuros; Holosteum umbellatum; Centaurium erythraea; Elymus caninus; Euphorbia esula; Vicia villosa; Chenopodium botrys; C. pedunculare; Amaranthus retroflexus; Digitaria sanguinalis 

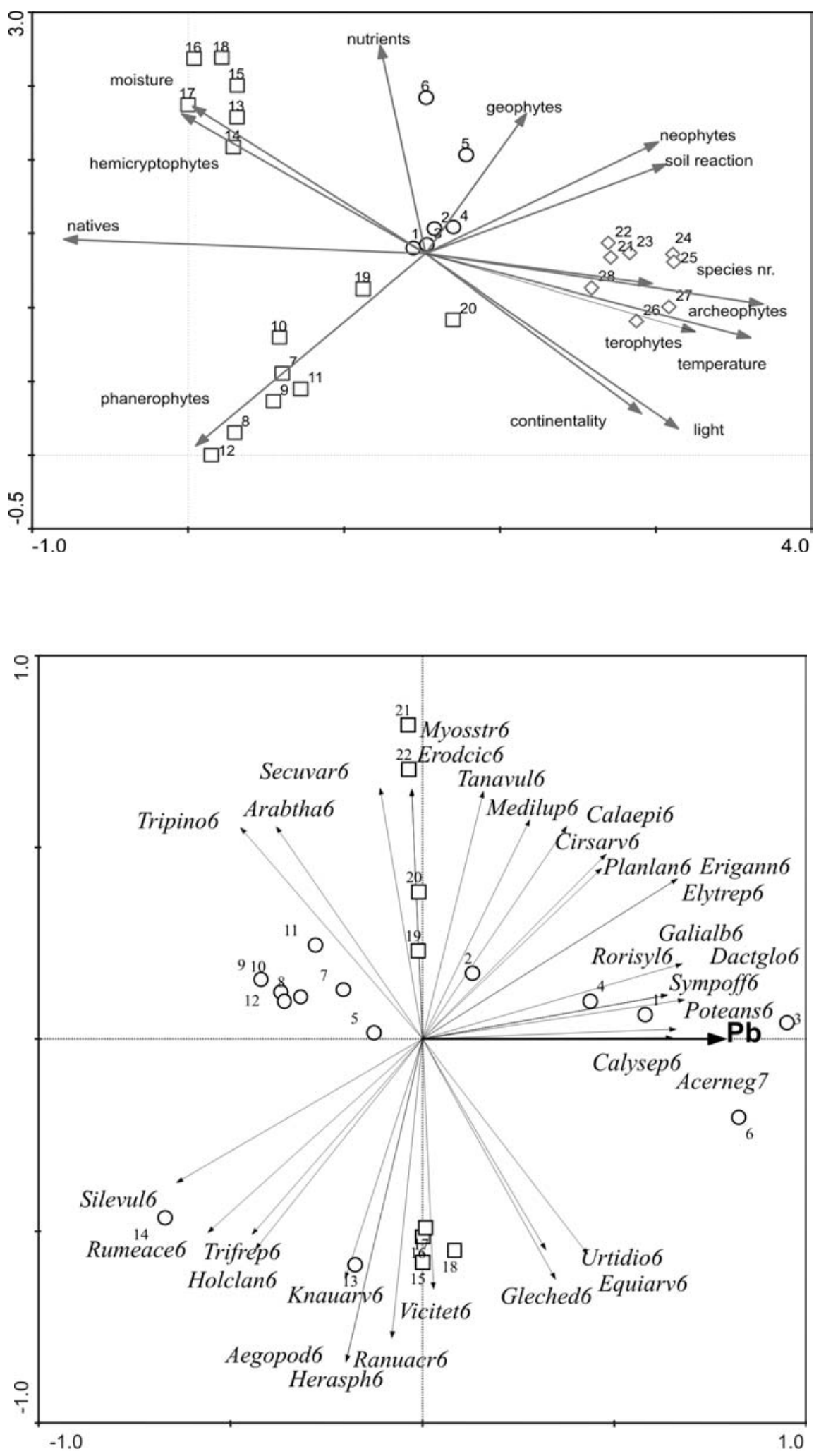

Fig. 2. Results of linear ordination method Principal Component Analysis (PCA) processed in CANOCO program and based on 28 samples from three study sites depicting pattern in their species composition. The Ellenberg indicator values (for light, nutrients, continentality, temperature, soil reaction, moisture), life form according to C. Raunkiær (hemicryptophytes, phanerophytes, terophytes, geophytes), species number per each plot, and native status according to Pyšek et al. (2002) were projected into ordination space as passive variables.

Fig. 3. Results of linear ordination method Redundancy Detrended Analysis (RDA) processed in CANOCO program with forward selection of variables (999 permutations tested by Monte Carlo test). Two study sites are shown (Kovohutě- circles, Spolana - squares) with arrow showing correlation of species composition with content of $\mathrm{Pb}$, a heavy metal, which passed through selection. Only 31 species best fitting with variables are shown. Abbreviations (6 means herbs, 7 means juveniles of tree): Acerneg7 - Acer negundo, Calaepi6 - Calamagrostis epigejos, Cirsarv6 - Cirsium arvense, Dactglo6 Dactylis glomerata, Elytrep6 - Elytrigia repens, Equiarv6 - Equisetum arvense, Erigann6 - Erigeron annuus, Gleched6 - Glechoma hederacea, Medilup6 - Medicago lupulina, Planlan6 - Plantago lanceolata, Poteans6 - Potentilla anserina, Rorisyl6 Rorripa sylvestris, Sympoff6 - Symphytum officinale, Tanavul6 - Tanacetum vulgare, Urtidio6 - Urtica dioica, Galialb6 - Galium album, Calysep6 - Calystegia sepium, Rumeace6 - Rumex acetosa, Ranuacr6 Ranunculus acris, Arabtha6 - Arabidopsis thaliana, Holclan6 - Holcus lanatus, Silevul6 - Silene vulgaris, Tripino6 - Tripleurospermum inodorum, Trifrep6 - Trifolium repens, Secuvar6 - Securigera varia, Aegopod6 - Aegopodium podagraria, Herasph6 Heracleum sphondylium, Knauarv6 - Knautia arvensis, Vicitet6 - Vicia tetrasperma, Myosstr6 - Myosotis stricta, Erodcic6 Erodium cicutarium. (see review done by Vaňková and Kovář 2004). Preliminary analysis shows that the species composition differs profoundly between these areas, and is characterized by only common species with wide ecological niches, which are able to colonize the toxic substrate.

The content of other heavy metals was not shown to be significantly associated with species composition. This is maybe due to the low number of sites. Similarly, no correlation between PCBs and plants was found, but there is lack of studies dealing with similar topic.
The variation in species composition explained by content of heavy metals in soil is not the only factor, and other unknown factors could be important for species occurrence in the sites (i.e. management - regular mowing, soil seed bank, species pool of neighbouring area) and without further experiments we cannot disentangle their effect, at all. For example, the enriching effect of neighbouring landscape for species diversity of species-poorer sedimentation basins was proved by Vaňková and Kovář (2004). 


\section{Possible remedial measures for sites}

The soil substrate is suitable for vegetation and is colonized by various plant species, apart of high toxic contents. Thus, no action is needed to reduce the initial toxicity of the sites studied. The obtained results may give us the possibility to select plant species for phytoremediation purposes. The plants suitable for phytoremediation should have not only a high ability to accumulate large amount of heavy metals or organic compounds, but also must be able to survive on soils with low mineral content and must produce a relatively high biomass (Cheng 2003a, b).

Since purification capacity of plants is species-specific and depends also on soil properties, we recommend studying the effects of nutrient or biosolids amendments at the sites studied (usually, the concentrations of trace elements and bioavailability by plants increase after fertilizing, see Adriano et al. 2004; Wu et al. 2004; Zahra et al. 2008). In addition, the role of mycorrhiza could play a role and enhance plant growth at toxic substrates.

\section{CONCLUSIONS}

Phytoremedy is relatively cost-effective compared to total removal of contaminated soil. However, when selecting hyper-accumulators, we must consider several factors (hyper-accumulator biomass production, their toxicity for wildlife, distribution of contaminants in their roots and shoots, long length of cropping cycle, enhancement of biological processes in the initial substrate, accumulation factor - uptake of minerals by plants compared to soil content (see Baker et al. 2000). Currently, we are not able to recognize such plants as the analyses of leaves content are under analyses. However, based on many studies, the most suitable species for phytostabilization, the grasses (Poaceae family) or tussock species with developed root system such as Calamagrostis epigejos and Elytrigia repens or Artemisia vulgaris (Asteraceae) are recommended as good bioindicators in the study areas (see e.g. Rebele et al. 1993, Lehmann and Rebele 2004a, b). Such species fulfil most of the criteria mentioned above and they are very frequent in order to assess variability.

\section{ACKNOWLEDGEMENT}

This work was supported by project NPV II (2B06187), NPV II (2B08058) and by the institutional long-term research plan AV0Z60050516 (Academy of Sciences of the Czech Republic). P. P. was supported by the Biodiversity Research Centre (grant nr. LC 06073 funded by Ministry of Education, Youth and Sports). We thank the anonymous reviewer for valuable comments.

\section{LITERATURE CITED}

ADRIANO D.C., WENZEL W.W., VANGRONSVELD J., BOLAN N.S. 2004. Role of assisted natural remediation in environmental cleanup. Geoderma 122: 121-142.

BAKER A.J.M., McGRATH S.P., REEVES R.D., SMITH J.A.C. 2000. Metal hyperaccumulator plants: a review of the ecology and physiology of a biological resource for phytoremediation of metal-polluted soils. In: Terry N., Bańuelos G. (eds), Phy- toremediation of contaminated soil and water. Lewis Publishers, Boca Raton, p. 359-376.

BARAZANI O., DUDAI N., KHADKA U.R., GOLAN-GOLDHIRSH A. (2004) Cadmium accumulation in Allium schoenoprasum L. grown in an aqueous medium. Chemosphere 57:1213-1218.

BREJ T., FABISZEWSKI J. 2006. Plants accumulating heavy metals in Sudety Mts. Acta Soc. Bot. Pol. 75: 61-68.

BRUELHEIDE H. 2000. A new measure of fidelity and its application to defining species groups. J. Veg. Sci. 11: 167-178.

CHENG S. 2003a. Effects of heavy metals in plants and resistance mechanism. Environ. Sci. Pollut. Res. 10: 250-264.

CHENG S. 2003b. Heavy metals in plants and phytoremediation. Environ. Sci. Pollut. Res. 10: 335-340.

ELLENBERG H., WEBER H.E., DÜLL R., WIRTH V., WERNER W., PAULISSEN D. 1992. Zeigerwerte von Pflanzen in Mitteleuropa. Ed. 2. Scripta Geobot. 18: 1-258.

HILL M.O. 1979. TWINSPAN. A Fortran program for arranging multivariate data in an ordered two-way table by classification of the individuals and attributes. Cornell Univ., New York.

KUBÁT K., HROUDA L., CHRTEK J., KAPLAN Z., KIRSCHNER J., ŠTĚPÁNEK J. (eds). 2002. Klíč ke květeně České republiky. Academia, Praha.

KUČEROVÁ M., WIESCHE C., WOLTER M., MACEK T., ZADRAŽIL F., MACKOVÁ M. 2001. The ability of different plant species to remove polycyclic aromatic hydrocarbons and polychlorinated biphenyls from incubation media. Biotechnol. Letters 23: 1355-1359.

LEHMANN C., REBELE F. 2004a. Assessing the potential for cadmium phytoremediation with Calamagrostis epigejos: a pot experiment. Int. J. Phytorem. 6: 169-183.

LEHMANN C., REBELE F. 2004b. Evaluation of heavy metal tolerance in Calamagrostis epigejos and Elymus repens revealed copper tolerance in a copper smelter population of $C$. epigejos. Environ. Experim. Bot. 51: 199-213.

MENDEZ M.O., MAIER R.M. 2008. Phytoremediation of mine tailings in temperate and arid environments. Rev. Environ. Sci. Biotechnol. 7: 47-59.

PETŘÍK P., BRUELHEIDE H. 2006. Species groups can be transferred across different scales. J. Biogeogr. 33: 1628-1642.

PYŠEK P., SÁDLO J., MANDÁK B. 2002. Catalogue of alien plants of the Czech Republic. Preslia 74: 97-186.

REBELE F., SURMA A., KUZNIK C., BORNKAMM R., BREJ T. 1993. Heavy metal contamination of spontaneous vegetation and soil around the copper smelter "Legnica". Acta Soc. Bot. Pol. 62: 53-57.

SOUDEK P., PETŘÍK P., VÁGNER M., PODRACKÁ E., TYKVA R., PLOJHAR V., PETROVÁ Š., VANĚK T. 2007. Botanical survey and screening of plant species which accumulate 226Ra from contaminated soil of uranium waste depot. Eur. J. Soil Biol. 43: 251-261.

TER BRAAK C. J. F., ŠMILAUER P. 2002. CANOCO reference manual and CanoDraw for Windows. User's guide Software for canonical community ordination (version 4.5). Microcomputer Power, Ithaca.

TICHÝ L. 2002. JUICE, software for vegetation classification. J. Veg. Sci. 13: 451-453.

VAŇKOVÁ J., KOVÁŘ P. 2004. Plant species diversity in the biotopes of unreclaimed industrial deposits as artificial islands in the landscape. In: Kovář P. (ed.), Natural recovery of human-made deposits in landscape, Academia, p. 30-45.

WU L.H., LI H., LUO Y.M., CHRISTIE P. 2004. Nutrients can enhance phytoremediation of copper-polluted soil by Indian mustard. Environ. Geochem. Health 26: 331-335.

ZAHRA A., MESDAGHINIA A., NOURI J., HOMAEE M., YUNESIAN M., AHMADIMOGHADDAM M., MAHVI A.H. 2008. Effect of fertilizer application on soil heavy metal concentration. Environ. Monitor. Assess. DOI 10.1007/ s10661-008-0659-x 